\title{
KEEPING RAZUVAEV'S TRADITIONS ALIVE
}

\author{
A.V. Gushchin, gushchin@chem.unn.ru \\ Lobachevsky State University of Nizhny Novgorod, Nizhny Novgorod, Russian Federation
}

The role of Grigory Alekseyevich Razuvaev in establishment of organometallic chemistry at the subdepartment of organic chemistry and chemistry department of Lobachevscky State University of Nizhny Novgorod is in arrangement of indissoluble connection between academic activity and scientific research work.

On September the 1st the academic year for the first-year students of the chemical department of Lobachevscky UNN traditionally begins in the memorial lecture room named after academician Grigory Alekseyevich Razuvaev, an honorary freeman of Nizhny Novgorod, a laureate of Lenin Prize and three State Prizes of the USSR, an outstanding scientist, the founder of organometallic chemistry in Nizhny Novgorod region.

G.A. Razuvaev appeared in Gorky State University in 1946 as a mature man that had studied in the school of the famous Russian chemist Professor Vladimir Nikolayevich Ipatiev (Leningrad Technological Institute, Petersburg), of Professor Georg Wieland (Germany), and after that in survival school in radium plant in Ukhta. He started his work in the capacity of the head of organic chemistry laboratory of the Scientific Research Institute at GSU, after which he took the baton of the head of organic chemistry subdepartment from the associate member of the USSR Academy of Sciences Professor Aleksandr Dmitrievich Petrov.

G.A. Razuvaev always was of opinion that it was possible to teach a student, to make him or her a selfsufficient thinking specialist, only by involving the student into research work, making it necessary to "stew" in a scientific research group of the world level. This idea was put into practice by him incessantly, in both his positions as the head of organic chemistry subdepartment (1946-1971) and the head of organic chemistry laboratory of the Scientific Research Chemistry Institute in GSU (from 1946). For a long time, from 1956 to 1962, Grigory Alekseyevich was the head of the Scientific Reseach Chemistry Institute; he initiated the

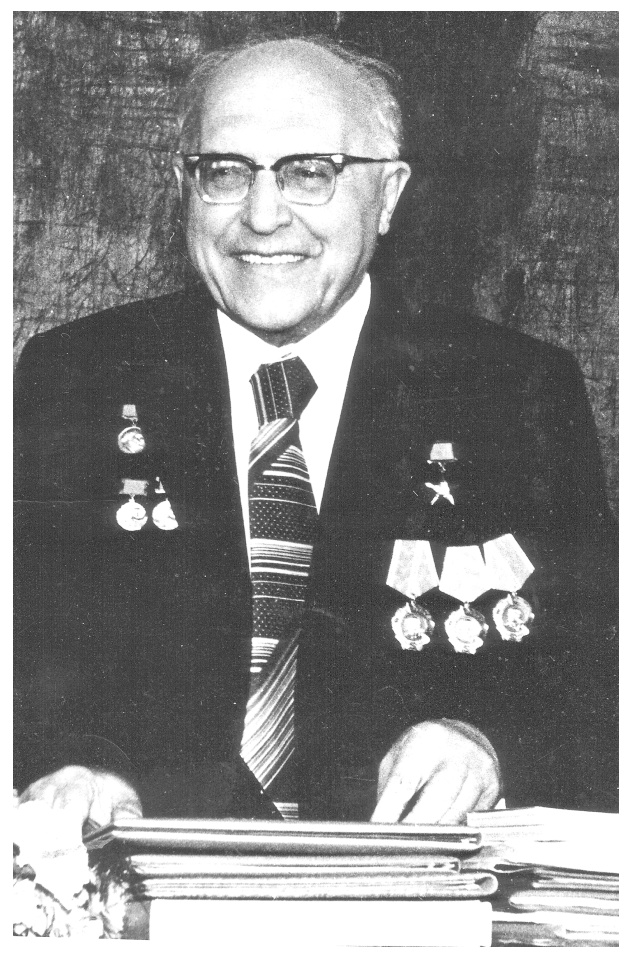
scientific collaboration of organic chemists with physicochemists, polymer chemists, analytical chemists and other specialists in the institute, involving them in widening of the field of scientific development in the new branch of organometallic chemistry. The new round of widening the connection between academic activity of chemical department and research activity in synthesis and reactions of organometallic compounds began in 1963, when the Laboratory of Polymer Stabilization of the USSR Academy of Sciences had been established in Gorky city under the direction of G.A. Razuvaev. Later it became the basis of formation of Chemistry Institute of the USSR Academy of Sciences (1969), and later still - of Institute of Organometallic Chemistry of the Russian Academy of Sciences (1988). The lecturers of the organometallic chemistry subdepartment and the researches in organometallic chemistry of the laboratories in Chemistry Institute within GSU and the research institute of the Academy. From 2005 to the present the filial branch of the organic chemistry subdepartment of UNN carries out its activities in Razuvaev Institute of Organometallic Chemistry of the Russian Academy of Sciences, under the direction of V.K. Cherkasov, the associate member of the Russian Academy of Sciences (Agreement dated 11.03.2005 between UNN and IOMC). In 2004 according to the order No. 2004-OD dated 02.12.2004 of UNN rector the base laboratory of coordination compounds of IOMC has been set up within the UNN chemistry department (the head of the laboratory is A.A. Trifonov, Doctor of Science (Chemistry), Professor). 


\section{Organometallic chemistry}

Institute of Organometallic Chemistry regularly hosts "Razuvaev Readings" once in 3 years in the format of all-Russian scientific conferences with international participation, on a Volga motor ship. For a week the leading world and Russian scientists in organometallic chemistry gather to discuss the problems of synthesis, study, coordination chemistry of organometallic compounds, their application in catalysis, synthesis of polymers and advanced materials. Postgraduate students and young scientists have the opportunity to communicate with distinguished scientists, to arrange for study courses and cooperative investigations, to participate in competitions of young researchers.

Close relationships between the Chemistry Institute of the Academy and the chemical department have been of great help in organization of access to modern research equipment, without which it is impossible to prepare the graduation papers by undergraduate and postgraduate students to an accomplished standard. In the hard period of "equipment hunger" the instruments for NMR, EPR, X-ray investigation in Razuvaev IOMC were placed at the disposal of the faculty and the students for free. Equipping of the department by its own top-class instrumentation began in 2006, when the presidential program for priority development of universities "Education" started (2006-2007), and then it continued with the program "National Research University" from 2009.

Within the program "Russian Academic Excellence Project" in 2014 the laboratory "Hightechnology materials on the basis of functional polymers and metal complex compounds (UNN IMOC)" was opened under the direction of associate member of the Russian Academy of Sciences D.F. Grishin, the head of subdepartment of petrochemistry and petrochemical synthesis; as well as the laboratory "Composite acrylate adhesives (UNN - IMOC - Kargin Polymer Research Institute)" under the direction of Professor V.A. Dodonov, the head of subdepartment of organic chemistry.

On terms of secondary employment, spare time work or in other forms many scientists were involved in research with the chemistry department students on the subject of chemistry of organometallic compounds: academician of the Russian Academy of Sciences G.A. Abakumov, associate members of the Academy G.A. Domrachev, V.K. Cherkasov, I.L. Fedyushkin, professors L.N. Zakharov, A.N. Egorochkin, M.N. Bochkarev, L.N. Bochkarev, B.B. Troitskiy, Yu.A. Kurskiy, A.A. Trifonov, M.P. Bubnov, A.G. Poddel'skiy, V.V. Semyonov, A.N. Kornev, A.V. Piskunov; the scientists of the Research Chemistry Institute of UNN: associate member of the Academy D.F. Grishin, professors I.V. Spirina, S.A. Bulgakova, N.N. Smirnova. That helped in improvement of education quality and ensured influx into student body.

Many organometallic chemists that consider themselves the disciples of Rasuvaev school, have become the heads of subdepartments and laboratories of other higher education institutions of Nizhny Novgorod and Russia, they have always made efforts to continue the scientific collaboration with the University of Nizhny Novgorod. Among them there are doctors of science V.A. Yablokov (State Architectural Building University of Nizhny Novgorod), S.F. Zhiltsov (Minin State Pedagogical University of Nizhny Novgorod), V.N. Latyaeva, A.S. Gordetsov (State Medical Academy of Nizhny Novgorod), V.V. Sharutin (South Ural State University), E.S. Klimov (Ul'yanovsk State Technical University), Yu.A. Ol'dekop, N.A. Mayer (Physical Organic Chemistry Institute of the Belarus National Academy of Sciences, Minsk), N.S. Vyazankin (Organic Chemistry Institute of the Academy of Sciences, Irkutsk), M.M. Koton (Institute of Macromolecular Compounds of the Academy of Sciences, Saint Petersburg), V.S. Etlis (Kargin Polymer Chemistry and Technology Research Institute, Dzerzhinsk in Nizhny Novgorod region), etc.

After G.A. Razuvaev from 1971 to 2015 the head of the subdepartment of organic chemistry was Professor Viktor Alekseyevich Dodonov, D.Sc.(Chem.), Honored Science Worker of the Russian Federation, the full member of the Russian Academy of Engineering Sciences, Honorable Professor of UNN, Honored Worker of UNN, Fulbright professor (1996, 2001), Soros professor, who qualified 3 Doctors of Science, 27 Candidates of Science; he is an author of 40 patents and author's certificates, 450 scientific papers. From 2015 the position has been held by Aleksey Yurievich Fyodorov, D.Sc.(Chem.), Professor, the head of the Chemistry Thesis Board.

The organic chemistry subdepartment qualifies bachelors and masters majoring in "Chemistry", specialists in "Fundamental and applied chemistry", candidates and doctors of sciences in "Organic chemistry" and "Organometallic chemistry". Guideline courses in organic chemistry, organometallic chemistry and life-science chemistry. Special courses for specialists, masters and postgraduate students have been prepared: "Metal complex catalysis", "Application of organometallic compounds of transition 
metals in organic synthesis", "Reactions of organoelemental compounds of non-transition metals with oxygen and peroxides". Joint Russian-French post-graduate studies are in practice.

Scientific research is carried out in the field of synthesis and study of structure and properties of organoelemental compounds of non-transition metals and peroxides, application of organometallic compounds in organic synthesis and catalysis, in production of biologically active substances and macromolecular compounds [1-7].

Lately, from 2006, the subdepartment has successfully been modernized and equipped with the modern instruments. All exhaust ventilation systems, the laboratories of student classes in organic chemistry, and a part of research laboratories have been repaired; costly equipment for physicochemical analysis of organic compounds has been established: IR-Fourier- and UV-spectrometers, as well as Shimadzu gas chromatographs, Knauer liquid chromatograph, NMR spectrometer Agilent DD2 400 $\mathrm{MHz}, \mathrm{CHNS}$ analyzer Vario EL Cube (Germany). Various instruments for laboratory practical training and graduation work has been acquired, such as modern rotary evaporators, magnetic stirrers, electronic balances, ultrasonic baths, muffle furnaces and drying cabinets, thermostats.

Young lecturers and postgraduate students work as trainees in the best laboratories and centers in Moscow, Saint Petersburg, England, Germany, France, USA.

Every year the subdepartment of organic chemistry carries out research work in grants and commercial contracts for approximately 10 million rubles, 20-25 scientific papers are published in the leading Russian and foreign journals, 2-4 patents and "know-hows" are registered, 1-2 theses are defended.

Along with other colleagues in the subdepartment of organic chemistry and chemistry department, I keep the memories of academician G.A. Razuvaev as a great scientist, one of the founders of the Russian organometallic chemistry, who was an indispensable member of organizing committees of Russian national and international conferences, who excelled in plenary reports demonstrating the vigor of Nizhny-Novgorod school of organometallic and peroxidic chemists. In my student days I was lucky to attend a few of Razuvaev's lectures. For a lifetime I have remembered his regular and serious "rounds of scientific groups", when the academician visited his original subdepartment. It was so amazing and unusual, that we, the members of students' scientific society, along with the instructors, were inquired about powders and solutions of reaction products standing under an exhaust hood. He intently examined them through thick lenses of his spectacles, offered advice what to study in literature, and in passing he instructed our supervisor (associate professor T.G. Brilkina) to train students to be more orderly, not to let them draw skull and crossbones on weighing bottles with substances... He noticed everything, remembered everything, in a week he asked what was new in your work, passed a note with a reference to an interesting paper.

\section{References}

1. Sharutin V.V., Senchurin V.S. Imennye reaktsii v khimii elementoorganicheskikh soedineniy [Name Reactions in Chemistry of Organoelemental Compounds]. Chelyabinsk, South Ural St. Univ. Publ., 2011. 426 p. (in Russ.)

2. Razuvaev G.A., Gribov B.G., Domrachev G.A., Salamatin B.A. Metallorganicheskie soedineniya $v$ elektronike [Organometallic Compounds in Electronics]. Moscow, Nauka Publ., 1972. 479 p. (in Russ.)

3. Nefedov O.M. Vospominaniya ob akademike Grigorii Alekseeviche Razuvaeve [Reminiscences about Academician Grigory Alekseyevich Razuvaev]. Moscow, Nauka Publ., 1992. 349 p. (in Russ.)

4. Petukhov G.G. Laureat Leninskoy premii professor G.A. Razuvaev [Laureate of Lenin Prize Professor G.A. Razuvaev] Trudy po khimii i khimicheskoy tekhnologii [Papers on Chemistry and Chemical Technology], 1958, vol. 1, pp. 439-444. (in Russ.)

5. Ol'dekop Yu.A., Mayer N.A. [To the 70th birthday and the 40th anniversary of scientific and pedagogical work]. Russian Journal of General Chemistry, 1966, vol. 36, iss. 2, pp. 3-6. (in Russ.)

6. Vasileyskaya N.S. Grigoriy Alekseevich Razuvaev [To the 80th birthday and the 50th anniversary of scientific and pedagogical work]. Russian Journal of Organic Chemistry, 1976, vol. 12, iss. 1, pp. 3-6. (in Russ.)

7. Tyutyunnik V.M. Khimiki - laureaty Leninskoy premii [Laureates of Lenin Prize in Chemistry]. Moscow, Znanie Publ., 1978. pp. 5-10. (in Russ.)

Received 10 September 2015 
Удк 547.1'13

\section{ТРАДИЦИИ РАЗУВАЕВА СОХРАНЯЕМ}

\section{A.B. Гущин}

Нижегородский государственный университет им. Н.И. Лобачевского, Нижний Новгород

\section{Литература}

1. Шарутин, В.В. Именные реакции в химии элементоорганических соединений / В.В. Шарутин, В.С. Сенчурин. - Челябинск: Издательский центр ЮУрГУ, 2011. - 426 с.

2. Металлорганические соединения в электронике / Г.А. Разуваев, Б.Г. Грибов, Г.А. Домрачев, Б.А. Саламатин. - М.: Наука, 1972. -479 с.

3. Нефедов, О.М. Воспоминания об академике Григории Алексеевиче Разуваеве / О.М. Нефедов. - М.: Наука, 1992. - 349 с.

4. Петухов, Г.Г. Лауреат Ленинской премии профессор Г.А. Разуваев / Г.Г. Петухов // Труды по химии и химической технологии. - 1958. - Т. 1. - С. 439-444.

5. Ольдекоп, Ю.А. Григорий Алексеевич Разуваев (К 70-летию со дня рождения и 40-летию научной и педагогической деятельности) / Ю.А. Ольдекоп, Н.А. Майер // Журн. общ. химии. 1966. - Т. 36. - Вып. 2. - С. 3-6.

6. Василейская, Н.С. Григорий Алексеевич Разуваев (К 80-летию со дня рождения и 50-летию научной и педагогической деятельности) / Н.С. Василейская // Журн. орг. химии. 1976. - Т. 12. - Вып. 1. - С. 3-6.

7. Тютюнник, В.М. Химики - лауреаты Ленинской премии / В.М. Тютюнник. - М.: Знание, 1978. - C. 5-10.

Гущин Алексей Владимирович - доктор химических наук, профессор, декан химического факультета, Нижегородский государственный университет им. Н.И. Лобачевского. 603950, г. Нижний Новгород, пр. им. Ю.А. Гагарина, 23. E-mail: gushchin@chem.unn.ru

Поступила в редакцию 10 сентября 2015 2.

\section{ОБРАЗЕЦ ЦИТИРОВАНИЯ}

Gushchin A.V. Keeping Razuvaev's Traditions Alive / A.V. Gushchin // Вестник ЮУрГУ. Серия «Химия». 2015. - T. 7, № 4. - C. 5-8.

\section{FOR CITATION}

Gushchin A.V. Keeping Razuvaev's Traditions Alive. Bulletin of the South Ural State University. Ser. Chemistry. 2015, vol. 7, no. 4, pp. 5-8. 